\title{
IDENTIFICATION OF COMPONENTS FOR THE EVALUATION OF FUNDED RESEARCH PROJECT: A SYSTEMATIC LITERATURE REVIEW
}

\author{
Kruthi Chikkaballapur Balaji, Poorvika Gopal \\ Researchers, Department of Industrial Engineering and Management, JSS campus, JSS Academy of \\ Technical Education, Uttarahalli-Kengeri Road, Bangalore - 560060, Affiliated to Visvesvaraya \\ Technological University, Belagavi, Karnataka,
}

\author{
Rashmi Srinivasaiah \\ Assistant Professor Department of Industrial Engineering and Management, JSS campus, JSS Academy \\ of Technical Education, Uttarahalli-Kengeri Road, Bangalore - 560060, Karnataka, India.
}

Devappa Renuka Swamy

Professor Department of Industrial Engineering and Management, JSS campus, JSS Academy of Technical Education, Uttarahalli-Kengeri Road, Bangalore - 560060, Karnataka, India.

\begin{abstract}
Objective: The purpose of this paper is to identify different components that can help to determine the effect of study findings and to identify different methodologies as well. To clarify the extent of the study on the impact assessment of funded initiatives in various countries, a systematic literature review is carried out.

Methodology: It is important to consider the effects of scientific findings to achieve value for the resources spent in science and technology. A systematic literature review (SLR) is carried out to gain a detailed understanding of the different literature available in the area of assessment of the search results of the projects funded. A total of $\mathbf{7 2}$ papers are collected from Google scholars to perform the SRL, which are screened according to the requirements for inclusion and exclusion.
\end{abstract}

Further 20 papers, primarily focusing on two study fields, namely the academic and health care industries, are accepted. The $\mathbf{2 0}$ papers chosen are mapped accordingly based on the market, country of origin, variables, and approaches used by different authors.

Conclusion: To determine the most significant variables commonly used by numerous writers in their studies, a systematic literature review is undertaken. The methodologies used by writers in their studies are also identified in this study. This paper can also be used by other researchers to describe in their studies the components and methodologies commonly used.

Originality/Value: The current research assists policymakers in making decisions on which components to examine when assessing funded initiatives that improve the effects, quality, and productivity in the higher educational sectors, and there has been relatively limited research in this field.

Keywords: Impact Assessment, Funded-Projects, Systematic review, Higher educational institutions.

\section{INTRODUCTION}

Individuals, groups of individuals, and institutions are sometimes granted funds to perform a study, research, or project. The funds don't have to be reimbursed, but the institutions go through a competitive application process to receive the funds. One of the main factors driving economic growth is technological advancement. Hence, a fair share of the economy is devoted to technological advancements. The initiatives are supported not only by government agencies but also by private institutions, businesses, trusts and foundations, direct endowments, and specific fundraising initiatives and non-profit organizations. For example, The National Institutes of 


\section{International Journal of Engineering Applied Sciences and Technology, 2021 \\ Vol. 6, Issue 3, ISSN No. 2455-2143, Pages 257-268 \\ Published Online July 2021 in IJEAST (http://www.ijeast.com)}

Health (NIH) and the National Science Foundation (NSF) in the United States, for example, spend over $\$ 30$ billion on basic and applied science research. (Jacob and Lefgren, 2007) ${ }^{1}$. Between 2014 and 2020, the European Union spent approximately $€ 80$ billion in science, predominantly through Horizon 2020, its flagship research program. This EU funding typically comes in the form of grants, which are used to partially support a wide variety of research projects. Similarly, the New Zealand government under the Creative Communities Scheme (CCS) supports more than 1800 projects every year.

Developing countries such as India have a strong emphasis on improving science and technology and advanced research, which is very important for the country's economic growth and development. Given this fact, the Government of India established the Department of Science and Technology (DST) in 1971 intending to promote science and technology activities across India. The Department has a wide variety of operations, ranging from the promotion of high-end basic research and development of state-of-the-art technology, on the one hand, to meet the technical needs of the ordinary citizen through the development of relevant skills and technologies, on the other.

The Oxford Dictionary delineates impact as a 'marked effect or influence.' However, the Research Excellence Framework (REF), 'Assessment framework and guidance on submissions' (REF2014 2011b) ${ }^{2}$ severely limits the interpretation of 'impact' to include an influence on, change in, or advantage to the economic system, community, cultural norms, policymaking or service providers, wellness, the ecosystem, or quality of life outside of academia.

Focusing on academic impacts, funded projects seem to positively influence certain tangible and intangible outcomes. As a result, this paper aims to define the components that will assist in the assessment of funded research's academic impact. Funding organizations can use the results to guide the allocation of funds where they are needed.

Need for the present study and analysis

Developing countries devote a significant portion of their economies to project funding. As a consequence, it is critical to evaluate the impact of these funded initiatives. To evaluate, a questionnaire has to be designed by considering appropriate indicators. A suitable combination of indicators can be found by conducting a systematic literature review.

\section{OBJECTIVE}

A Systematic Literature Review (SLR) identifies, evaluates, and conducts increased evidence to understand specified questions. The purpose of this study is to perform a comprehensive literature review to identify the components for evaluating funded research projects. Hence SLR is adopted to fulfill the aim of this study.

\section{METHODOLOGY}

This section gives a brief picture of the methodology adopted to conduct the research. Along with a Systematic Literature Review, Pareto analysis suggests the vital few components used by several authors. The components can be sorted and arranged using "Pareto analysis" in the order of criticality (Karuppusami and Gandhinathan, 2006) ${ }^{3}$. This approach can be applied to identify the components to evaluate funded research projects. The aim of using Pareto Analysis is to look at the components used by different authors and see how much they appear. This, in turn, provides details on where effort should be prioritized.

A Systematic Literature Review (SLR) recognizes, qualifies, and conducts high-frequency evidence to understand stated questions (Dewey A. \& Drahota A. $2016)^{4}$. For a systematic assessment, a well-defined procedure or approach should be used where the criteria are stated even before a review is conducted. It is a thorough, direct search across numerous archives and research articles that many other scholars can replicate and expand. It entails creating a search algorithm with a particular emphasis or that adequately answers a given query. The analysis describes the set of content searched, criticized and written, within known timelines. The review must include all search terms, search methods (such as site names, platforms, search dates), and constraints. Systematic literature reviews emerged in healthcare and are associated with evidence-based practice According to Grant and Booth, (2009) ${ }^{5}$ "The growth of evidence-based practice has resulted in a growing diversity of review styles". They juxtapose 14 study approaches, detailing the strengths and drawbacks of each review. The objective of this SLR is to evaluate and analyze research outcomes in different educational institutions. The study has been carried out in the following steps: literature review, inclusion, and exclusion criteria development, analysis \& conclusion.

Research Question: 


\section{International Journal of Engineering Applied Sciences and Technology, 2021 \\ Vol. 6, Issue 3, ISSN No. 2455-2143, Pages 257-268 \\ Published Online July 2021 in IJEAST (http://www.ijeast.com)}

This research focuses on the following questions:

Question 1: How many Indian authors have focused their research on the Evaluation of Impacts of Funded Projects?

Question 2: Does funded research publications have a greater effect on citation impacts than unfunded research publications?

Question 3: What main academic and research factors help evaluate the impact of funded projects and research?

Question 4: What are the different research methodologies and statistical analysis used by various authors in their studies to evaluate the impact of funded research projects?

Question 5: What are the various academic outcomes in different academic institutions which have been funded for their projects and research?

Inclusion and Exclusion criteria development:

Judgments may be made on the impact of the inclusion and exclusion criteria on the external validity of the findings. Determining such choices requires a thorough knowledge of the study area as well as a comprehension of how each criterion may affect the experiment's accuracy (Patino and Ferreira, 2018) . $^{6}$ Inclusion criteria are everything that a thesis needs to offer in order to be included in a review's examination. The exclusion criteria are the characteristics that would render a study ineligible for inclusion in a review. Dates, how the research was planned, population, outcomes, and so on are examples of these criteria. This inclusion and exclusion criteria development takes place in two stages firstly, domain criteria secondly, the language criteria. The first inclusion criteria include published documents, papers, or articles which have not been published in journals yet are excluded. The domain is the next criteria that identify the area of focus of the research. In this case, the papers falling under 'Research outcomes of funded projects are included. However,

\section{Search Terms:}

The terms and keywords used to find research papers: Impact evaluation, Research Outcomes, Academic Institutions, Health care sector, Funded projects, DST - FIST programs. funded studies on funded projects by NGOs and nonfunded projects are excluded. The final criteria are the language of the manuscript, any language other than English is excluded from the study.

Table 1: Inclusion and Exclusion Criteria

\begin{tabular}{|c|c|c|}
\hline Criteria & Inclusion & Exclusion \\
\hline $\begin{array}{c}\text { Document } \\
\text { Type }\end{array}$ & $\begin{array}{c}\text { Published } \\
\text { documents }\end{array}$ & $\begin{array}{c}\text { Ongoing, } \\
\text { Unpublished, or } \\
\text { upcoming } \\
\text { documents. }\end{array}$ \\
\hline Domain & $\begin{array}{c}\text { Research outcomes } \\
\text { of funded projects in } \\
\text { different institutions }\end{array}$ & $\begin{array}{c}\text { Funded projects } \\
\text { by NGOs, Non- } \\
\text { funded projects. }\end{array}$ \\
\hline Language & English & $\begin{array}{c}\text { Other than } \\
\text { English }\end{array}$ \\
\hline
\end{tabular}

Databases and search strategies

A total of "72" published papers were selected and downloaded from the internet. Out of "72" papers, the number of papers finally accepted for the study is 20 . Certain search terms and search strings are fed to google scholars to find the papers. After reviewing the paper suggested by google scholar results, the references of that paper are also looked into for further more papers. For example, a study named "Evaluation of the Impact of NBCF funded research" by Donavan et al., (2014) $)^{7}$ mentions certain other APA citations of studies in its references, which helped in finding more studies related to impact evaluation of funded projects. "Evaluation of NHMRC funded research completed in 1992,1997 and 2003" by Kingwell et al., (2006) ${ }^{8}$ is one of the papers taken from the reference section of the study conducted by Donavan et al., (2014) ${ }^{7}$. The search terms and their combinations used to search for relevant papers on google scholar are as follows:

Search Strings:

Search strings used to find research papers on google scholar are:

"Impact evaluation" And "Funded projects"

"Funded projects" And "Health Care Sector"

"Funded projects" And "Academic institutions"

"Impact evaluation" And "DST - FIST programs"

"Research outcomes" And "Funded projects"

"Research outcomes" And "Academic Institutions"

Document selection 


\section{International Journal of Engineering Applied Sciences and Technology, 2021 \\ Vol. 6, Issue 3, ISSN No. 2455-2143, Pages 257-268 \\ Published Online July 2021 in IJEAST (http://www.ijeast.com)}

The papers download is segregated into academic and health care sectors. However, papers focusing on social impacts are excluded from the study. 52 papers focusing on academic outputs were initially obtained, whereas, 20 papers on health care sectors. 15 out of the 36 screened academic papers are accepted and 3 out of 20 screened health care papers. Reasons for the other 54 papers not being screened and not accepted could be due to

(i) lack of accessibility of specific data such as variables, methods, or statistical analysis used by the authors

(ii) a substantial emphasis on social impacts

(iii) NGO funding.

Table 2: Document Selection

\begin{tabular}{|c|c|c|c|}
\hline Sectors & Initial & Screened & Accepted \\
\hline Academic & 52 & 36 & 15 \\
\hline $\begin{array}{c}\text { Health } \\
\text { Care }\end{array}$ & 20 & 20 & 05 \\
\hline Total & 72 & 30 & 20 \\
\hline
\end{tabular}

\section{LITERATURE REVIEW}

There is a growing demand in many Western countries for new forms of audit, review, and performance reports that disclose and visualize the results of the funded projects in public sector organizations (Pollitt and Bouckaert, 2000) $)^{9}$. Hence, several recent studies are being centered on evaluating the effects of funds and grants for health, research, and development programs. While there has been a great deal of research in the healthcare sector to continuously enhance the quality of medicines and therapies, few researchers have taken into account the effect of funds for various research and academic projects for academic institutions.

A tabular overview of the numerous recent research papers concerning the impact assessment of funded projects and most frequently used indicators are given in table number 3 .

Table 3: Literature Review Table

\begin{tabular}{|c|c|c|c|c|c|}
\hline $\begin{array}{l}\text { Sl } \\
\text { no }\end{array}$ & Author & Objective & Indicators & Methodology & Outcome \\
\hline 1. & $\begin{array}{l}\text { Kinkel and } \\
\text { Henke } \\
(2006)^{10}\end{array}$ & $\begin{array}{l}\text { To compare the effects on } \\
\text { academic success, educational } \\
\text { preparation, and career growth } \\
\text { of funded undergraduate } \\
\text { research }\end{array}$ & $\begin{array}{l}\text { educational } \\
\text { planning, } \\
\text { Academic } \\
\text { performance, and } \\
\text { Career } \\
\text { development }\end{array}$ & $\begin{array}{l}\text { Comparative } \\
\text { study }\end{array}$ & $\begin{array}{l}\text { Undergraduate students actively } \\
\text { participating in research activities observed } \\
\text { optimistic results in their academics and } \\
\text { were immediately employed than those } \\
\text { students who lacked funding for their } \\
\text { research. }\end{array}$ \\
\hline 2. & $\begin{array}{l}\text { Goldfarb } \\
(2008)^{11}\end{array}$ & $\begin{array}{l}\text { To analyze the impact of a } \\
\text { sponsor and identify the } \\
\text { shortcomings of the process for } \\
\text { grant funding for academic } \\
\text { research }\end{array}$ & $\begin{array}{l}\text { Funding, Research } \\
\text { outcomes } \\
\text { (Publications and } \\
\text { citations), } \\
\text { Researcher fields }\end{array}$ & $\begin{array}{l}\text { Three-stage least } \\
\text { squares } \\
\text { estimation } \\
\text { technique }\end{array}$ & $\begin{array}{l}\text { As a result of continued involvement with } \\
\text { the funding agencies, research output } \\
\text { exhibits declination due to a lack of } \\
\text { utilitarian objectives on the works and } \\
\text { projects. }\end{array}$ \\
\hline 3 & $\begin{array}{l}\text { Carol et al., } \\
(2015)^{12}\end{array}$ & $\begin{array}{l}\text { Present the findings of } \\
\text { evaluative research that has } \\
\text { gathered and evaluated } \\
\text { evidence of the potential of } \\
\text { such funding to promote } \\
\text { productive abilities and the } \\
\text { effect it has had on recipients. }\end{array}$ & $\begin{array}{l}\text { Project funding, } \\
\text { Academic progress, } \\
\text { Organization } \\
\text { culture. }\end{array}$ & $\begin{array}{l}\text { Quantitative } \\
\text { and qualitative } \\
\text { analysis }\end{array}$ & $\begin{array}{l}\text { It is observed that funding leaves an } \\
\text { optimistic impact on professional } \\
\text { enhancement when induced with } \\
\text { strengthened teaching and project } \\
\text { management skills practice. The work } \\
\text { environment also ultimately affects the } \\
\text { incidence of innovation. }\end{array}$ \\
\hline 4 & $\begin{array}{l}\text { Gusic et al., } \\
(2010)^{13}\end{array}$ & $\begin{array}{l}\text { To examine the effect of } \\
\text { projects } \quad \text { on } \quad \text { faculty }\end{array}$ & $\begin{array}{l}\text { Products of project } \\
\text { work, academic }\end{array}$ & $\begin{array}{l}\text { Mixed Approach } \\
\text { Method }\end{array}$ & $\begin{array}{l}\text { Accomplishing the projects leads to the } \\
\text { development of new skills and establishes }\end{array}$ \\
\hline
\end{tabular}




\begin{tabular}{|c|c|c|c|c|c|}
\hline & & $\begin{array}{l}\text { development, within the } \\
\text { Pennsylvania State University } \\
\text { College of Medicine. }\end{array}$ & $\begin{array}{l}\text { productivity, career } \\
\text { development }\end{array}$ & & $\begin{array}{l}\text { a concentration on their careers. The } \\
\text { highest number of academic products } \\
\text { (publications, presentations, and grants) } \\
\text { and the highest number of overall } \\
\text { achievements associate with the faculty } \\
\text { who made the most progress on their } \\
\text { projects. }\end{array}$ \\
\hline 5 & $\begin{array}{l}\text { Gulbrandsen } \\
\text { and Smeby } \\
(2005)^{14}\end{array}$ & $\begin{array}{l}\text { To explore the relationship } \\
\text { between industrial funding and } \\
\text { (a) academic outcomes } \\
\text { (b) research collaboration }\end{array}$ & $\begin{array}{l}\text { Profile of research } \\
\text { collaboration, } \\
\text { patents, and } \\
\text { scientific } \\
\text { publishing }\end{array}$ & $\begin{array}{l}\text { Descriptive } \\
\text { statistical and } \\
\text { Regression } \\
\text { analysis }\end{array}$ & $\begin{array}{l}\text { The paper shows that university professors } \\
\text { associate industry funding with applied } \\
\text { research more than development work. } \\
\text { Industrially funded professors publish } \\
\text { more than their peers with no external } \\
\text { funding. Industrial funding and } \\
\text { collaboration are also closely associated } \\
\text { with patent development. }\end{array}$ \\
\hline 6 & $\begin{array}{l}\text { Fan et al., } \\
(2019)^{15}\end{array}$ & $\begin{array}{l}\text { Exploring the effect of funding } \\
\text { sources on the success of } \\
\text { universities in innovation }\end{array}$ & $\begin{array}{l}\text { Regulation } \\
\text { implementation, } \\
\text { innovation climate } \\
\text { of the university, } \\
\text { Management } \\
\text { mechanism. }\end{array}$ & $\begin{array}{l}\text { Structural } \\
\text { equation } \\
\text { modeling } \\
\text { using partial least } \\
\text { squares }\end{array}$ & $\begin{array}{l}\text { Government funding has a higher effect on } \\
\text { regulatory enforcement, and industrial } \\
\text { funding has a higher impact on the } \\
\text { development of management systems. The } \\
\text { results have shown that only industrial } \\
\text { funding has a beneficial impact on the } \\
\text { climate of innovation at a university. }\end{array}$ \\
\hline 7 & $\begin{array}{l}\text { Dougherty } \\
\text { and Reddy } \\
(2011)^{16}\end{array}$ & $\begin{array}{l}\text { To evaluate the impact of } \\
\text { performance funding }\end{array}$ & $\begin{array}{l}\text { Student Outcomes, } \\
\text { Changes in } \\
\text { Organizational and } \\
\text { Policies status } \\
\text { Practices, } \\
\text { competition, } \\
\text { Knowledge } \\
\text { protection }\end{array}$ & Case Studies & $\begin{array}{l}\text { Performance funding increased status } \\
\text { competitions colleges, this, in turn, results } \\
\text { in implementing better policies for the } \\
\text { organization, enhancing student services } \\
\text { and opportunities. However, the result does } \\
\text { not show any evidence of an increase in the } \\
\text { student retention rate. }\end{array}$ \\
\hline 8 & $\begin{array}{l}\text { Jacob and } \\
\text { Lefgren } \\
(2011)^{17}\end{array}$ & $\begin{array}{l}\text { To examine the quality and } \\
\text { value of scientific productivity } \\
\text { of research productivity } \\
\text { associated with grant funding }\end{array}$ & $\begin{array}{l}\text { Citations, } \\
\text { Publications, and } \\
\text { Rank of graduate } \\
\text { institution }\end{array}$ & $\begin{array}{l}\text { Quasi-static } \\
\text { analysis }\end{array}$ & $\begin{array}{l}\text { We see that, before the grant submission, } \\
\text { researchers who were granted a grant } \\
\text { because they scored just below the cutoff } \\
\text { had lower efficiency. The average increase } \\
\text { of additional publications over the } \\
\text { succeeding } 5 \text { years was found to be } 7 \% \\
\text { more than the initial years before funding. }\end{array}$ \\
\hline 9 & $\begin{array}{l}\text { Zhao } \\
(2015)^{18}\end{array}$ & $\begin{array}{l}\text { To determine the impact of } \\
\text { grant-funded research in the } \\
\text { library and information science } \\
\text { field }\end{array}$ & $\begin{array}{l}\text { Citation counts, } \\
\text { Research Articles, } \\
\text { Funding agency }\end{array}$ & $\begin{array}{l}\text { Bibliometric } \\
\text { analysis }\end{array}$ & $\begin{array}{l}\text { Grant-funded research had a much greater } \\
\text { effect than other research, as assessed by } \\
\text { citation counts, both overall and in each } \\
\text { publication individually. The proportion of } \\
\text { journalists citing grant-funded research in } \\
\text { information-oriented publications was } \\
\text { considerably greater than in library- } \\
\text { focused ones. }\end{array}$ \\
\hline 10 & $\begin{array}{l}\text { Garg et al., } \\
(2005)^{19}\end{array}$ & $\begin{array}{l}\text { Assessing the impact of } \\
\text { AICTE funding on R\&D and } \\
\text { educational development }\end{array}$ & $\begin{array}{l}\text { Productivity, } \\
\text { Human resource } \\
\text { development, }\end{array}$ & $\begin{array}{l}\text { Data } \\
\text { Envelopment } \\
\text { Analysis }\end{array}$ & $\begin{array}{l}\text { About } 40 \% \text { of project investigators } \\
\text { propagated information through } \\
\text { conference papers. Data analysis shows }\end{array}$ \\
\hline
\end{tabular}




\section{International Journal of Engineering Applied Sciences and Technology, 2021 \\ Vol. 6, Issue 3, ISSN No. 2455-2143, Pages 257-268 \\ Published Online July 2021 in IJEAST (http://www.ijeast.com)}



\begin{tabular}{|c|c|c|c|c|c|}
\hline & & & $\begin{array}{l}\text { Education, } \\
\text { Linkages } \\
\text { established. }\end{array}$ & & $\begin{array}{l}\text { that } 72 \mathrm{PhDs} \text { were the product of } 17 \% \text { of } \\
\text { the programs. In } 26 \text { percent of projects, } 139 \\
\text { students pursued their PhDs. In } 34 \% \text { of } \\
\text { projects, } 334 \text { students completed their ME } \\
\text { degrees. } \\
\text { Compared to research and technical } \\
\text { efficiency, the study indicated that the } \\
\text { impact was greater in terms of human } \\
\text { resource capacity growth. }\end{array}$ \\
\hline 11 & $\begin{array}{l}\text { Jowkar et al., } \\
(2011)^{20}\end{array}$ & $\begin{array}{l}\text { To compare the citation effect } \\
\text { of Iranian-funded research } \\
\text { papers with those of non- } \\
\text { funded research. }\end{array}$ & $\begin{array}{l}\text { Fields, Funded, } \\
\text { Unfunded }\end{array}$ & $\begin{array}{l}\text { Bibliometric } \\
\text { method }\end{array}$ & $\begin{array}{l}\text { Around } 12.5 \text { percent of Iranian } \\
\text { publications were funded, and over the past } \\
\text { four years, the number of publications } \\
\text { funded has grown significantly. In nearly } \\
\text { all of the subject areas, the citation effect of } \\
\text { funded publications was substantially } \\
\text { higher. }\end{array}$ \\
\hline 12 & $\begin{array}{l}\text { Anguelov and } \\
\text { Ivanova } \\
(2018)^{21}\end{array}$ & $\begin{array}{l}\text { To clarify and evaluate the } \\
\text { university's internal variables } \\
\text { affecting the efficacy and } \\
\text { efficiency of project financing. }\end{array}$ & $\begin{array}{l}\text { Financial capacity; } \\
\text { Team capacity; } \\
\text { Image capacity; } \\
\text { Administrative } \\
\text { Capacity; } \\
\text { Infrastructure } \\
\text { capacity }\end{array}$ & $\begin{array}{l}\text { Statistical data } \\
\text { processing }\end{array}$ & $\begin{array}{l}\text { Of all the factors, the project team's } \\
\text { attributes, administrative capacity, and } \\
\text { financial capacity have a major impact. } \\
\text { Universities can use this assessment to } \\
\text { decide whether the project proposal has all } \\
\text { the potential benefits and consistency to } \\
\text { secure funds for grants or not. }\end{array}$ \\
\hline 13 & $\begin{array}{l}\text { Bozeman and } \\
\text { Gaughan } \\
(2007)^{22}\end{array}$ & $\begin{array}{l}\text { To study the effect of research } \\
\text { grant funding on the type and } \\
\text { scope of academic research and } \\
\text { technological collaborations } \\
\text { with industry. }\end{array}$ & $\begin{array}{l}\text { Demographic, } \\
\text { Career, Grant's } \\
\text { activity, } \\
\text { disciplinary } \\
\text { affiliation. }\end{array}$ & $\begin{array}{l}\text { Multivariate- } \\
\text { ate analysis. }\end{array}$ & $\begin{array}{l}\text { The research observation states that } \\
\text { academics who have research grants, as } \\
\text { well as contracts, collaborate most actively } \\
\text { with industry than those without brands or } \\
\text { contracts }\end{array}$ \\
\hline 14 & $\begin{array}{l}\text { Choi et al., } \\
(2009)^{23}\end{array}$ & $\begin{array}{l}\text { For a better understanding of } \\
\text { the impact of } R \& D \text { funding. }\end{array}$ & $\begin{array}{l}\text { Technology } \\
\text { performance, } \\
\text { Management } \\
\text { performance, } \\
\text { Business } \\
\text { performance } \\
\text { Manufacturing } \\
\text { performance, } \\
\text { Impacts }\end{array}$ & $\begin{array}{l}\text { Quantification } \\
\text { analysis } \\
\text { Clustering } \\
\text { analysis } \\
\text { Contingency } \\
\text { analysis. }\end{array}$ & $\begin{array}{l}\text { It is observed that firms with a research } \\
\text { department perform better than those } \\
\text { without a research department. Policy } \\
\text { imperatives were suggested for cluster } 1 \text { as } \\
\text { it showed relatively lower impacts than the } \\
\text { rest. }\end{array}$ \\
\hline 15 & $\begin{array}{l}\text { Frolich et al., } \\
(2010)^{24}\end{array}$ & $\begin{array}{l}\text { To explore how higher } \\
\text { education institutions and their } \\
\text { policies and core activities are } \\
\text { affected by funding } \\
\text { mechanisms. }\end{array}$ & $\begin{array}{l}\text { Type of funding, } \\
\text { Basic grants, } \\
\text { Budget, External } \\
\text { research grants }\end{array}$ & $\begin{array}{l}\text { Comparative } \\
\text { analysis }\end{array}$ & $\begin{array}{l}\text { The research at the machine level provides } \\
\text { an example of a pattern across Europe. The } \\
\text { paper shows that in all three nations, mixed } \\
\text { funding models were being adopted } \\
\text { (Denmark, Norway, and Portugal). }\end{array}$ \\
\hline 16 & $\begin{array}{l}\text { Clay et al., } \\
(2006)^{25}\end{array}$ & $\begin{array}{l}\text { Evaluation of the results of the } \\
\text { National Heart Foundation of } \\
\text { Australia research investment } \\
\text { (NHF) }\end{array}$ & $\begin{array}{l}\text { Level of research } \\
\text { funding, Visibility } \\
\text { of NHF-funded } \\
\text { research, Funding } \\
\text { level, Leverage of } \\
\text { research funding. }\end{array}$ & $\begin{array}{l}\text { Bibliometric } \\
\text { analysis. }\end{array}$ & $\begin{array}{l}\text { The observation from the research was } \\
\text { made like, } \\
\text { - Public health research funding increased } \\
\text { by } 75 \text { percent and } 26 \text { percent, especially for } \\
\text { individuals and projects. } \\
\text {-NHF funded research had high visibility }\end{array}$ \\
\hline
\end{tabular}




\section{International Journal of Engineering Applied Sciences and Technology, 2021 \\ Vol. 6, Issue 3, ISSN No. 2455-2143, Pages 257-268 \\ Published Online July 2021 in IJEAST (http://www.ijeast.com)}

\begin{tabular}{|c|c|c|c|c|c|}
\hline & & & & & $\begin{array}{l}\text { than other funded researches in high impact } \\
\text { journals } \\
\text { - Citation rates (6.4) were higher than the } \\
\text { country (6.1) and world benchmark (5.4) } \\
\text { - Further leveraged the support of } \$ 1.5 \\
\text { million. }\end{array}$ \\
\hline 17 & $\begin{array}{l}\text { Donovan et } \\
\text { al., }(2014)^{7}\end{array}$ & $\begin{array}{l}\text { To assess the effect of the } \\
\text { National Breast Cancer } \\
\text { Foundation's } \\
\text { (NBCF's) research investment. }\end{array}$ & $\begin{array}{l}\text { Research } \\
\text { Type, Funding, } \\
\text { Duration, Cost, } \\
\text { Payback categories }\end{array}$ & $\begin{array}{l}\text { Bibliometric } \\
\text { analysis. }\end{array}$ & $\begin{array}{l}\text { These were evaluated and concluded from } \\
\text { the research, } \\
\text {-Seventy surveys }(46 \%) \text { recorded career } \\
\text { advancement, and } 185 \text { reported career } \\
\text { progressions } \\
\text { Higher degrees, including } 121 \mathrm{PhDs} \text {, have } \\
\text { also been acquired or planned. } \\
\text {-Hundred and one grant }(66 \%) \text { provided } \\
\text { research system-wide capacity-building } \\
\text { resources, and research teams leveraged an } \\
\text { additional } \$ 1.40 \text { in support for each dollar } \\
\text { invested. } \\
\text { - Actual research had a higher effect on } \\
\text { knowledge generation and regenerative } \\
\text { medicine, while applied research had a } \\
\text { larger influence on the other Payback } \\
\text { categories. }\end{array}$ \\
\hline 18 & $\begin{array}{l}\text { Silvestre et al., } \\
(2016)^{26}\end{array}$ & $\begin{array}{l}\text { To see whether there was a link } \\
\text { between scholarly influence, as } \\
\text { assessed by the h-index, and } \\
\text { the receipt of National } \\
\text { Institutes of Health (NIH) grant } \\
\text { money among academic plastic } \\
\text { surgeons. }\end{array}$ & $\begin{array}{l}\text { Status, Academic } \\
\text { rank, and Terminal } \\
\text { degree(s). }\end{array}$ & $\begin{array}{l}\text { correlation } \\
\text { coefficient } \\
\text { analysis. }\end{array}$ & $\begin{array}{l}\text { A clear connection between academic } \\
\text { influence and funding procurement was } \\
\text { observed. As calculated by the h-index, } \\
\text { faculty with higher funding had a greater } \\
\text { scholarly effect, which indicates that this } \\
\text { instrument could be helpful during the } \\
\text { selection process for the NIH grant. }\end{array}$ \\
\hline 19 & $\begin{array}{l}\text { Hanney et al } \\
(2004)^{27}\end{array}$ & $\begin{array}{l}\text { To outline the strategies to be } \\
\text { used to analyze the outcomes } \\
\text { of the study sponsored by the } \\
\text { UK Arthritis Research } \\
\text { Campaign. }\end{array}$ & $\begin{array}{l}\text { Payback categories: } \\
\text { Knowledge } \\
\text { production, } \\
\text { Capacity building, } \\
\text { Research } \\
\text { Targeting, } \\
\text { Informing policy } \\
\text { Absorption, } \\
\text { Product } \\
\text { development, } \\
\text { Health benefits, and } \\
\text { Broader economic } \\
\text { benefits }\end{array}$ & $\begin{array}{l}\text { Semi-structured } \\
\text { interviews } \\
\text { Literature } \\
\text { review, and } \\
\text { bibliometric } \\
\text { analysis }\end{array}$ & $\begin{array}{l}\text { The methods for presenting the findings of } \\
\text { research funded by the Arthritis Research } \\
\text { Campaign have been validated by a pilot } \\
\text { analysis. }\end{array}$ \\
\hline 20 & $\begin{array}{l}\text { Boulding et } \\
\text { al., }(2020)^{28}\end{array}$ & $\begin{array}{l}\text { To map the diversity of studies } \\
\text { into public health and to } \\
\text { recognize examples of impacts. }\end{array}$ & Payback Model & $\begin{array}{l}\text { Quantitative } \\
\text { analysis and } \\
\text { Semi-structured } \\
\text { analysis with } \\
\text { Principal }\end{array}$ & $\begin{array}{l}89 \% \text { of NIHR portfolio projects suggest a } \\
\text { substantial overlap of fields that relate to } \\
\text { the findings of public health studies. The } \\
\text { other impact examples include establishing } \\
\text { partnerships of trust with local bodies, }\end{array}$ \\
\hline
\end{tabular}




\section{International Journal of Engineering Applied Sciences and Technology, 2021 \\ Vol. 6, Issue 3, ISSN No. 2455-2143, Pages 257-268 \\ Published Online July 2021 in IJEAST (http://www.ijeast.com)}

Investigators

understanding unintentional collaborations and networks of non-academic dissemination.

After studying through many publications, it is well acknowledged that the objective purposes and conclusions of the above literature seem to assess the impacts of funded projects. Bibliometric analysis is the most common and productive method used by researchers to examine the impacts Gusic et al.,(2008) $)^{13}$, Jacob and Lefgren (2011) ${ }^{17}, \quad$ Zhao $(2015)^{18}$, Jowkar et al., (2011) $)^{20}$, Clay et al.,(2006) $)^{25}$, Goldfarb $(2008)^{11}$. Bibliometrics is a quantitative method to quantify the outcomes of the research. They are suitable for repeated analysis and comparisons can be used to manage large amounts of data and can be very cost-effective (A Boaz et al., 2009) ${ }^{29}$. The Payback Framework was initially developed to evaluate the impacts of health services research
Donovan et al., (2014) $)^{7}$, Clay et al., $(2006)^{25}$. However, literature related to academic outcomes supports a) citations b) increase in publications c) patents d) career development e) collaborations f) work environment g) organizational policies as components to be considered. Although a few Indian researchers are working on this topic, it is scarce to find Indian literature focused on the evaluation of academic outputs of funded projects. However, Indian research focuses more on the social effects of funded initiatives. It is essential for developing countries like India to evaluate the academic outputs as it invests a good percentage of its economy in the development of Science and Technology.

Table 4: Components and Frequencies

\begin{tabular}{|c|c|c|}
\hline Indicators & Authors & Frequency \\
\hline Citations & $\begin{array}{l}\text { Gusic et al.,(2008) })^{13} \text {, Jacob and Lefgren }(2011)^{17} \text {, Zhao }(2015)^{18} \text {, } \\
\left.\text { Jowkar et al., }(2011)^{20} \text {, Clay et al.,(2006) }\right)^{25}, \text { Goldfarb }(2008)^{11}\end{array}$ & 6 \\
\hline $\begin{array}{l}\text { Increase } \quad \text { in } \\
\text { Publications }\end{array}$ & $\begin{array}{l}\text { Gusic et al.,(2008) })^{13} \text {, Jowkar et al., }(2011)^{20} \text {, Jacob and Lefgren } \\
(2011)^{17} \text {, Goldfarb }(2008)^{18} \text {, Gulbrandsen and Smeby }(2005)^{14}\end{array}$ & 5 \\
\hline Patents & Gulbrandsen and Smeby $(2005)^{14}$, Donovan et al., $(2014)^{7}$ & 2 \\
\hline Career Development & $\begin{array}{l}\text { Garg et al., }(2005)^{19} \text {, Donovan et al., }(2014)^{7} \text {, Kinkel and Henke }(2006) \text {, } \\
\text { Carol et al., }(2015)^{12} \text {, Dougherty and Reddy }(2011)^{16} \text {, Bozeman and } \\
\text { Gaughan }(2007)^{22} \text {, Silvestre et al., }(2016)^{26}\end{array}$ & 7 \\
\hline Collaboration & Gulbrandsen and Smeby $(2005)^{14}$, Bozeman and Gaughan $(2007)^{22}$ & 2 \\
\hline Work Environment & Fan et al., $(2019)^{15}$, Carol et al., $(2015)^{12}$ & 2 \\
\hline $\begin{array}{l}\text { Quality of } \\
\text { publications }\end{array}$ & $\begin{array}{l}\text { Goldfarb }(2008)^{11}, \text { Zhao }(2015)^{18} \text {, Clay et al., }(2006)^{25}, \text { Silvestre et al., } \\
(2016)^{26}\end{array}$ & 4 \\
\hline $\begin{array}{l}\text { Organizational } \\
\text { policies }\end{array}$ & $\begin{array}{l}\text { Dougherty and Reddy }(2011)^{16}, \text { Anguelov and Ivanova }(2018)^{21} \text {, Choi } \\
\text { et al., }(2009)^{23} \text {, Donovan et al., }(2014)^{7}\end{array}$ & 4 \\
\hline
\end{tabular}

Identification of Components
A graph with bars in ascending order of the frequencies is a Pareto diagram. The lengths of the bars represent frequency or cost (time or money) and 


\section{International Journal of Engineering Applied Sciences and Technology, 2021 \\ Vol. 6, Issue 3, ISSN No. 2455-2143, Pages 257-268 \\ Published Online July 2021 in IJEAST (http://www.ijeast.com)}

are ordered with the longest on the left and the shortest on the right. The graph thus visually indicates that the circumstances are more significant. This illustrates both the extent and the cumulative effect of defects. Pareto Charts are useful in identifying the defects to prioritize to observe the greatest overall change. In this context, Pareto analysis is conducted to identify the factors which contribute the most to interpret the impact of funded research projects.

\section{Pareto Chart of C1}

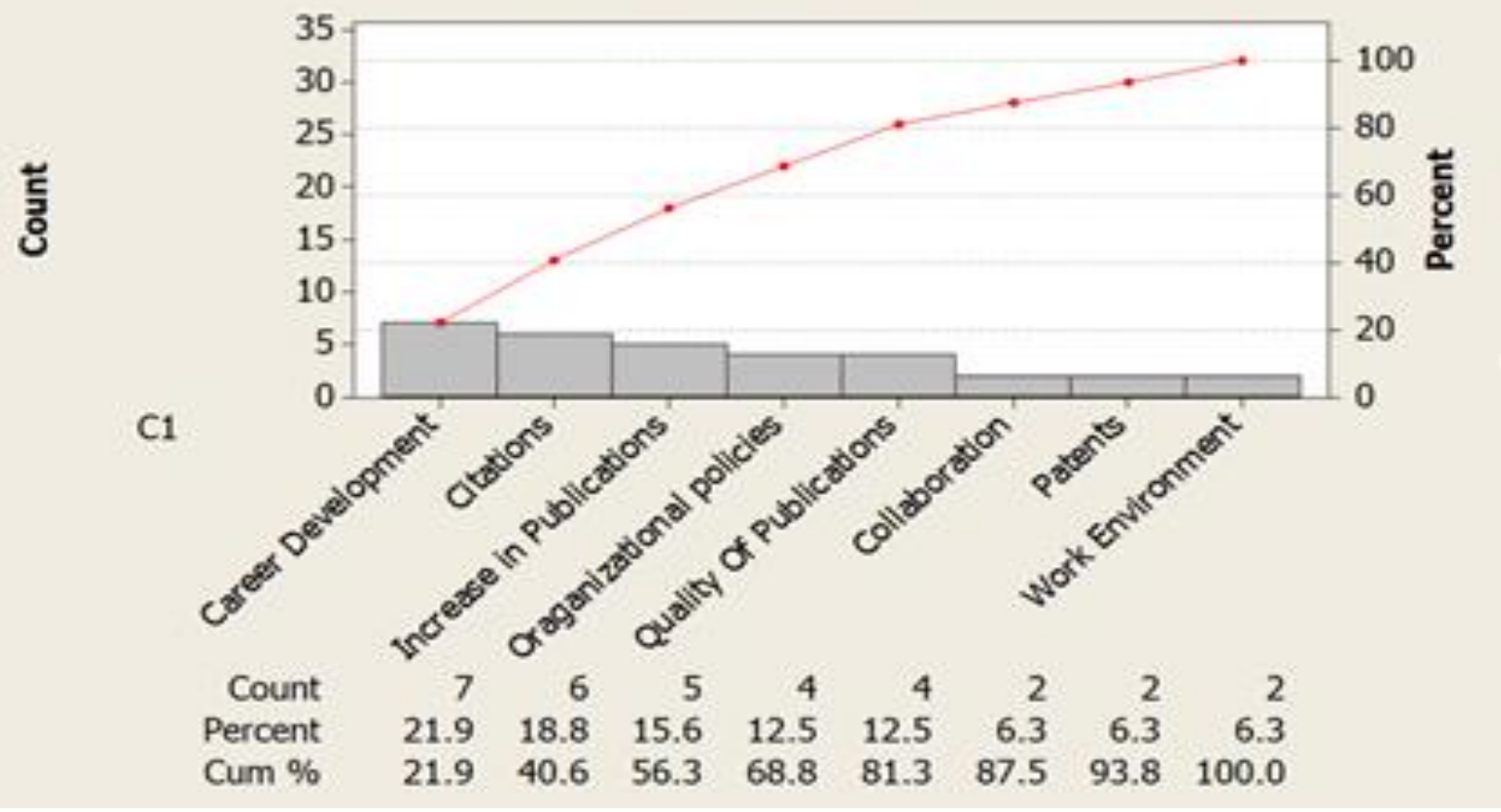

The above Pareto chart represents the indicators based on their frequencies. It infers that Career Development, Citations, and Increase in Publications are the most effective indicators of research outcomes. Organizational Policies and Quality of Publications have a moderate effect and about $80 \%$ of the effect on the outcomes of the academic research is caused by the above-mentioned five indicators. Indicators like Collaboration, Patents, and Work Environment are least effective with comparatively very few frequencies. The results of this analysis help in determining which component to focus more on to get higher quality research outcomes from the academic departments.

Table 5 lists the articles that have been categorized by author and year, as well as by journals, countries, and the number of citations that each work has received.

Table 5: Paper Classification

\begin{tabular}{|l|l|l|l|l|}
\hline Sl No & Author \& year & Journal & Country & Citations \\
\hline 1 & Kinkel and Henke (2006) ${ }^{10}$ & $\begin{array}{l}\text { Natural Resources and Life Sciences } \\
\text { Education }\end{array}$ & United States & 63 \\
\hline 2 & Goldfarb (2008) $)^{11}$ & Research Policy & United States & 188 \\
\hline
\end{tabular}


International Journal of Engineering Applied Sciences and Technology, 2021

Vol. 6, Issue 3, ISSN No. 2455-2143, Pages 257-268

Published Online July 2021 in IJEAST (http://www.ijeast.com)

\begin{tabular}{|c|c|c|c|c|}
\hline 3 & Carol et al., $(2015)^{12}$ & Engineering Education & England & 5 \\
\hline 4 & Gusic et al., $(2008)^{13}$ & Academic Medicine & United States & 52 \\
\hline 5 & Gulbrandsen and Smeby $(2005)^{14}$ & Research Policy & Norway & 897 \\
\hline 6 & Fan et al., $(2019)^{15}$ & $\begin{array}{l}\text { Technology Analysis \& Strategic } \\
\text { Development }\end{array}$ & Taiwan & 4 \\
\hline 7 & Dougherty and Reddy $(2011)^{16}$ & College Research Center & Columbia & 188 \\
\hline 8 & $\underline{\text { Jacob }}$ and Lefgren $(2011)^{17}$ & Journal of public economics & United States & 345 \\
\hline 9 & Zhao $(2010)^{18}$ & Scientometrics \& AKJournals & Hungary & 84 \\
\hline 10 & Garg et al., $(2005)^{19}$ & Scientometrics \& AKJournals & INDIA & 23 \\
\hline 11 & Jowkar et al., $(2011)^{20}$ & $\begin{array}{l}\text { Aslib Proceedings: New Information } \\
\text { Perspectives }\end{array}$ & Iran & 30 \\
\hline 12 & Anguelov and Ivanova $(2018)^{21}$ & $\begin{array}{lcc}\text { International } & \text { Conference } & \text { on High } \\
\text { Technology } & \text { for } & \text { Sustainable } \\
\text { Development, } & \text { HiTech } & 2018 \\
\text { Proceedings } & & \end{array}$ & Bulgaria & 6 \\
\hline 13 & Bozeman and Gaughan $(2007)^{22}$ & Research Policy & United States & 388 \\
\hline 14 & Choi et al., $(2009)^{23}$ & Research Policy & South Korea & 22 \\
\hline 15 & Frolich et al., $(2010)^{24}$ & $\begin{array}{l}\text { International Journal of Educational } \\
\text { Management }\end{array}$ & $\begin{array}{l}\text { Denmark, } \\
\text { Norway \& } \\
\text { Portugal }\end{array}$ & 105 \\
\hline 16 & Clay et al., $(2006)^{25}$ & Medical Journal of Australia & Australia & 16 \\
\hline 17 & Donovan et al., $(2014)^{7}$ & Medical Journal of Australia & Australia & 32 \\
\hline 18 & Silvestre et al., $(2016)^{26}$ & Plastic and Reconstructive Surgery & United States & 25 \\
\hline 19 & Hanney et al., $(2004)^{27}$ & Health Research Policy and Systems & $\begin{array}{l}\text { United } \\
\text { Kingdom }\end{array}$ & 141 \\
\hline 20 & Boulding et al., $(2020)^{28}$ & BMC medical research methodology & $\begin{array}{l}\text { United } \\
\text { Kingdom }\end{array}$ & 2 \\
\hline
\end{tabular}

\section{CONCLUSIONS AND DISCUSSION}

While there are several different methods of performing a literature review, it has been proven that a systematic literature review offers a consistent and thorough summary of existing evidence on a particular subject. SLR made it possible to classify the factors used by the authors to assess the effects of funded projects utilizing a systematic literature review. Factors such as citations, enhancement in the quality of publications, and patents are important measures of impact evaluation. Funds for infrastructure upgrades 


\section{International Journal of Engineering Applied Sciences and Technology, 2021 Vol. 6, Issue 3, ISSN No. 2455-2143, Pages 257-268 \\ Published Online July 2021 in IJEAST (http://www.ijeast.com)}

will put a constructive view of the working environment to the fore. The work environment for the faculties, career growth of students, and faculties make up several other components reflecting academic outputs. Different methodologies used by various authors for different fields are also established, in addition to variables. To gain knowledge about the citation impacts, some authors perform bibliometric analysis, while authors focusing on the health care sectors use Herg's Pay-Back System Model to evaluate the impacts, especially in Australia's national health institutes. Although Indian authors work on studies related to impact assessment, they are more focused on the social impacts. The present study does not focus on social impacts or broader economic impacts hence, this study can be further expanded by including different fields.

\section{REFERENCES}

1. Jacob, B., \& Lefgren, L. (2007). The impact of research grant funding on scientific productivity.

2. Penfield, T., Baker, M. J., Scoble, R., \& Wykes, M. C. (2014). Assessment, evaluations, and definitions of research impact: A review. Research evaluation, 23(1), 21-32.

3. Karuppusami, G., \& Gandhinathan, R. (2006). Pareto analysis of critical success factors of total quality management: A literature review and analysis. The TQM magazine.

4. Dewey, A. \& Drahota, A. (2016) Introduction to systematic reviews: online learning module Cochrane Training https://training.cochrane.org/interactivelearn ing/module-1-introduction-conductingsystematic-reviews

5. Grant, M. J., \& Booth, A. (2009). A typology of reviews: an analysis of 14 review types and associated methodologies. Health information \& libraries journal, 26(2), 91108.

6. Patino, C. M., \& Ferreira, J. C. (2018). Inclusion and exclusion criteria in research studies: definitions and why they matter. Jornal Brasileiro de Pneumologia, 44, 84-84.

7. Donovan, C., Butler, L., Butt, A. J., Jones, T. H., \& Hanney, S. R. (2014). Evaluation of the impact of National Breast Cancer
Foundation-funded research. Medical Journal of Australia, 200(4), 214-218.

8. Kingwell, B. A., Anderson, G. P., Morris, M. E., Duckett, S. J., Hoole, E. A., RothwellShort, J., ... \& Wilson, A. J. (2006). Evaluation of NHMRC funded research completed in 1992, 1997 and 2003: gains in knowledge, health and wealth. Medical journal of Australia, 184(6), 282-286.

9. Pollitt, Christopher and Geert Bouckaert (2000), Public Management Reform, Oxford: Oxford University Press.

10. Kinkel, D. H., \& Henke, S. E. (2006). Impact of undergraduate research on academic performance, educational planning, and career development. Journal of Natural Resources and Life Sciences Education, 35(1), 194-201.

11. Goldfarb, B. (2008). The effect of government contracting on academic research: Does the source of funding affect scientific output?. Research Policy, 37(1), 41-58.

12. Carol, A., Alison, S., \& Harry, T. (2007). An evaluation of the impact of small-scale funding on the professional practices of engineering academics. engineering education, 2(1), 13-22.

13. Gusic, M. E., Milner, R. J., Tisdell, E. J., Taylor, E. W., Quillen, D. A., \& Thorndyke, L. E. (2010). The essential value of projects in faculty development. Academic Medicine, 85(9), 1484-1491.

14. Gulbrandsen, M., \& Smeby, J. C. (2005). Industry funding and university professors' research performance. Research policy, 34(6), 932-950.

15. Fan, H. L., Huang, M. H., \& Chen, D. Z. (2019). Do funding sources matter?: The impact of university-industry collaboration funding sources on innovation performance of universities. Technology Analysis \& Strategic Management, 31(11), 1368-1380.

16. Dougherty, K. J., \& Reddy, V. T. (2011). The impacts of state performance funding systems on higher education institutions: Research literature review and policy recommendations.

17. Jacob, B. A., \& Lefgren, L. (2011). The impact of research grant funding on scientific productivity. Journal of public economics, 95(9-10), 1168-1177.

18. Zhao, D. (2010). Characteristics and impact of grant-funded research: a case study of the 


\section{International Journal of Engineering Applied Sciences and Technology, 2021 \\ Vol. 6, Issue 3, ISSN No. 2455-2143, Pages 257-268 \\ Published Online July 2021 in IJEAST (http://www.ijeast.com)}

library and information science field. Scientometrics, 84(2), 293-306.

19. Garg, K. C., Gupta, B. M., Jamal, T., Roy, S., \& Kumar, S. (2005). Assessment of impact of AICTE funding on $R \& D$ and educational development. Scientometrics, 65(2), 151160.

20. Jamali, H. R., Jowkar, A., Didegah, F., \& Gazni, A. (2011, November). The effect of funding on academic research impact: a case study of Iranian publications. In Aslib Proceedings. Emerald Group Publishing Limited.

21. Anguelov, K., \& Ivanova, M. (2018, June). Impact factors in implementation of EUfunded projects in Bulgarian Higher Education Institutions. In 2018 International Conference on High Technology for Sustainable Development (HiTech) (pp. 1-5). IEEE.

22. Bozeman, B., \& Gaughan, M. (2007). Impacts of grants and contracts on academic researchers' interactions with industry. Research policy, 36(5), 694-707.

23. Choi, J. Y., Lee, J. H., \& Sohn, S. Y. (2009). Impact analysis for national $R \& D$ funding in science and technology using quantification method II. Research Policy, 38(10), 15341544.

24. Frølich, N., Schmidt, E. K., \& Rosa, M. J. (2010). Funding systems for higher education and their impacts on institutional strategies and academia. International Journal of Educational Management.

25. Clay, M. A., Donovan, C., Butler, L., \& Oldenburg, B. F. (2006). The returns from cardiovascular research: the impact of the
National Heart Foundation of Australia's investment. Medical journal of Australia, 185(4), 209-212.

26. Silvestre, J., Abbatematteo, J. M., Chang, B., Serletti, J. M., \& Taylor, J. A. (2016). The impact of National Institutes of Health funding on scholarly productivity in academic plastic surgery. Plastic and Reconstructive Surgery, 137(2), 690-695.

27. Hanney, S. R., Grant, J., Wooding, S., \& Buxton, M. J. (2004). Proposed methods for reviewing the outcomes of health research: the impact of funding by the UK's' Arthritis Research Campaign'. Health research policy and systems, 2(1), 4.

28. Boulding, H., Kamenetzky, A., Ghiga, I., Ioppolo, B., Herrera, F., Parks, S., ... \& Hinrichs-Krapels，S. (2020). Mechanisms and pathways to impact in public health research: a preliminary analysis of research funded by the National Institute for Health Research (NIHR). BMC medical research methodology, 20(1), 1-20.

29. Boaz, A., Fitzpatrick, S., \& Shaw, B. (2009). Assessing the impact of research on policy: a literature review. Science and Public Policy, 36(4), 255-270. 